\section{濃縮菌体の一部排出培養法による高酸度 食酢の連続生産における培養温度の影響十}

$$
\text { 玉井正弘*·丸子 修**・門 隆興* }
$$

Effect of the Cultivation Temperature on

Continuous Production of Vinegar at

High Acidity by Partial Discharging of Cell-Concentration Broth

(Improvement of the Vinegar Brewing

Process Using Bioreactor, Part V)

$$
\begin{aligned}
& \text { Masahiro TAMAI*, Osamu MARUKO** } \\
& \text { and Takaoki } \mathrm{KADO}^{*}
\end{aligned}
$$

\section{* Hiroshima Prefectural Food Technology Research Center, 12-70, Hijiyama-honmachi, Minami-ku. Hiroshima-shi, Hiroshima 732 \\ ${ }^{* *}$ Mitsubishi Rayon Engineering Co., Ltd., 20-1, Miyuki-cho, Ohtake-shi, Hiroshima 739-06}

To raise the acetic acid concentration and enhance productivity, the effect of cultivation temperature in the second fermentor was studied on continuous production of vinegar using hollow fiber module and two fermentors. In the second fermentor, the cells were concentrated with a hollow fiber module and some portion of concentrated cells were discharged to suppress excessive increase in cell concentration. Cultivation temperature was regulated at $30^{\circ} \mathrm{C}$ in the first fermentor and varied from 20 to $30^{\circ} \mathrm{C}$ in the second fermentor. Fresh medium of an ethanol concentration of $13 \%(\mathrm{v} / \mathrm{v})$ at a rate of $100 \mathrm{~m} l / \mathrm{h}$ was fed. A broth containing $117 \mathrm{~g}$-acetic acid/l of acetic acid and $0.114 \mathrm{~g}-\mathrm{dry}$ cell $/ l$ of cell was produced in the first fermentor and supplied to the second fermentor. In the second fermentor, cells were concentrated with a hollow fiber module and was discharged at a discharge ratio of 0.1 . The acetic acid concentration reached 156 g-acetic acid $/ l$ at $24^{\circ} \mathrm{C}$ and was constant below $24^{\circ} \mathrm{C}$. Total acetic acid production rate and the yield of both fermentors was $3.0 \mathrm{~g}$-acetic acid $(l \cdot$ h) and $0.94 \mathrm{~g}$-acetic acid/1.304 g-consumed ethanol respectively. In the acetic acid production, the ratio of contribution of the first and second fermentor was estimated as $0.72: 0.28$.

(Received, Jan. 20, 1997 ; Accepted, May 22, 1997)

著者らは，前報》において連続的に第 1 槽で $116 \mathrm{~g}$ acetic acid /lの酢酸之菌体を生産し，第 2 槽で第 1 槽加 ら供給された菌体を中空糸膜モジュールを用いて菌体濃 度を高めることにより, $143 \mathrm{~g}$-acetic acid $/ l$ の食酢を連 続的に生産できることを報告した。また，菌体を発醉槽 外に排出しない完全濃縮培養法では，酢酸生産に寄与し ない菌体を多量に蓄積しでろ過に要する経費が増加す るために，濃縮菌体の一部を排出することにより酢酸潡 度が $10 \%(\mathrm{w} / \mathrm{v})$ の場合 ${ }^{3)}$ と同様に培養液中の菌体湢度 を低く抑えることができた。しかしながら，初期の目標 であった $15 \%(\mathrm{w} / \mathrm{v})$ 浱度の酢酸は生産できなかった。

ここで，回分培養におけるエタノール，酢酸等の一次 代謝産物は, 生産物浱度が上昇した時に培養温度を低下 させることにより，生産物の生産速度は低下するが，生 産物阻害の影響を軽减でき，結果として目的生産物質の 最終濃度を向上できることが知られている．本研究に使 用している菌株も培養温度を低下させることにより， $18 \%(\mathrm{w} / \mathrm{v})$ 以上の酢酸を生産できることから, 連続生 産においても培養温度を低下させることにより，酢酸に よる生産物阻害を軽減してより高濃度の食酢を生産でき る可能性がある.

そこで, 高酸度 $(15 \%(\mathrm{w} / \mathrm{v}))$ 食酢の効率的な連続生 産と共に菌体濃度の過度の増加を抑制することを目的と

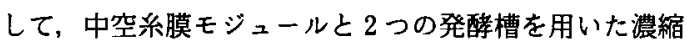
菌体の一部排出培養を行い，第 2 槽の培養温度が䣫酸発 醉に及ぼす影響について検討した結果について報告す ろ.

\section{1. 実験方法}

（1）供試菌株

既報”と同様に，広島県内の食酢醇造場の発醉被より

分離・選択した菌株 No. 11 を用いた。

(2) 培地組成

前報と同様にエタノール濃度が $13 \%(\mathrm{v} / \mathrm{v})$ の培地を 用いた。

(3) 培養方法

前報之同様の装置を用いて行い，第 1 槽への新鮮培地

けバイオリアクターによる食酢製造工程の改善に関する研究（第 5 報）(前報, 文献 1)）

*広島県立食品工業技術センター（干732 広島県広島市南区比治山本町 12-70）

** 三菱レイヨン・エンジニアリング株式会社（テ739-06 広島県大竹市御幸町 20-1） 
及び第 2 槽への 99.5\%（v/v) エタノールの供給は，100 及び $4.2 \mathrm{ml} / \mathrm{h}$ の一定速度で行った，培養温度は，第 1 槽 で $30^{\circ} \mathrm{C}$ 一定，第 2 槽で $28 ， 26 ， 24,22$ と $20^{\circ} \mathrm{C}$ で変化さ

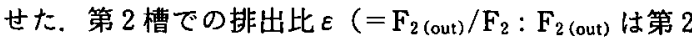
槽からの菌体含有液の排出速度, $F_{2}$ は第 1 槽からの培養 液の排出速度と第 2 槽への $99.5 \%(\mathrm{v} / \mathrm{v})$ エ夕ノールの 供給速度の合計）は, 0.1 で行った.

(4) 分析

酢酸，エタノール及び菌体は既報2) と同様に行った。

\section{2. 実験結果及び考察}

（1）酢酸，エタノール上菌体濃度

前報において，第 1 槽において $116 \mathrm{~g}$-acetic acid $/ l の$ 酢酸と菌体を生産し、これを第 2 槽に供給しつつ中空系 膜モジュールを用いて菌体の一部濃縮を行うことによ り，第 2 槽において酢酸濃度を $27 \mathrm{~g}$-acetic acid $/ l$ 高め ることができた。 この時，第 1 槽及び第 2 槽の培養温度 を $30^{\circ} \mathrm{C}$ で酢酸発酵を行ったが，培養温度を低下させる ことにより生産物阻害を軽減してより高酸度の食酢を生 産できる可能性がある。

そこで，より酢酸濃度が高くなって生産物阻害の影響 が大きくなる第 2 槽の培養温度を $28,26,24,22$ 及び $20^{\circ} \mathrm{C}$ で変化させて酢酸発酵に与える影響を検討した。

第 2 槽中の酢酸, エタノ一ル及び菌体濃度に与える培 養温度の影響を Fig. 1 に示した，第 1 槽における培養温 度及び培地供給速度は， $30^{\circ} \mathrm{C}$ 及び $100 \mathrm{ml} / \mathrm{h}$ の一定であ るために, 第 1 槽中の酷酸, エタノール及び菌体濃度は, いずれもほぼ一定であった．第 1 槽中の酢酸, エタノー ル及び菌体濃度は, 平均で $117 \mathrm{~g}$-acetic acid $/ l, 9.0 \mathrm{~g}-$ ethanol $/ l$ 及び $0.114 \mathrm{~g}$-dry cell $/ l$ と前報" ${ }^{1} の$ 值と同程度 であった，第 2 槽中の酢酸濃度は，培養温度が低下する につれて $24^{\circ} \mathrm{C}$ まで次第に増加し, $24^{\circ} \mathrm{C}$ で $156 \mathrm{~g}$-acetic acid $/ l$ に達し，目的とする $15 \%(w / v)$ の食酢を連続的 に生産できた。この結果, 第 2 槽で增加した酢酸濃度は $30^{\circ} \mathrm{C}$ では $27 \mathrm{~g}$-acetic acid $/ l$ であったが, $24^{\circ} \mathrm{C}$ では酢 酸による生産物阻害の軽減により $39 \mathrm{~g}$-acetic acid $/ l$ に 増加した，さらに，培養温度を $20^{\circ} \mathrm{C}$ まで低下させたが酢 酸濃度は増加しなかった，東出ら゙)の報告によると，回 分発醉による酢酸発酵において酶酸濃度が高くなった場 合, $20^{\circ} \mathrm{C}$ 以下の低温に保持することにより最終酢酸濃度 はより高濃度になり，阻害は軽減されることを報告して いるが，本研究では，培養温度の低下による酢酸濃度の 増加の効果は $24^{\circ} \mathrm{C}$ までであった. しかしながら, 培養温 度を低下させることにより培養に要する日数は增加する 傾向にあり，酢酸生産速度が低下していることが推定で

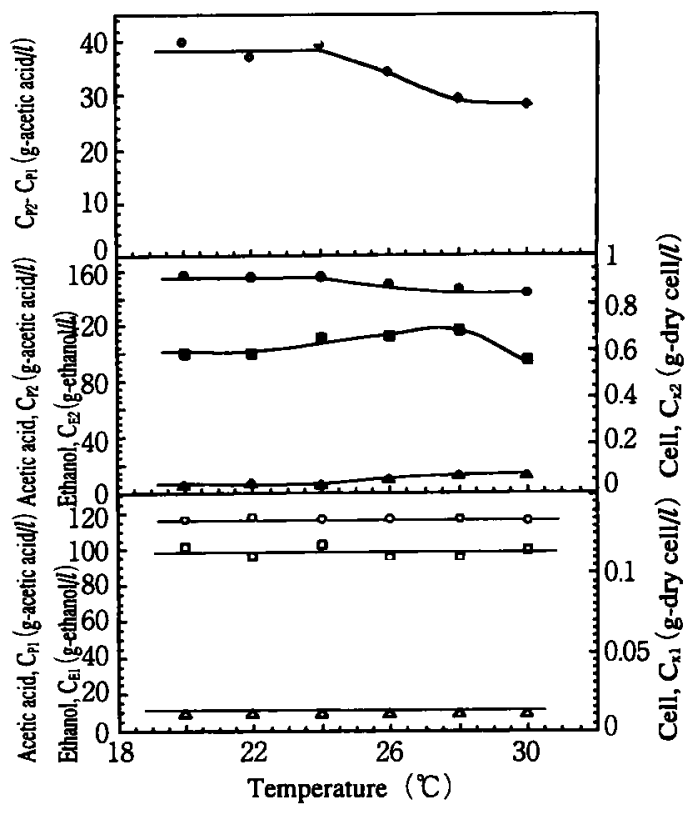

Fig. 1 Effect of cultivation temperature on acetic acid, ethanol, cell concentration and $\mathrm{C}_{\mathrm{P} 2}-\mathrm{C}_{\mathrm{P} 1}$

Cultivation temperature indicate the second fermentor. Cultivation temperature in the first fermentor was regulated at $30^{\circ} \mathrm{C}$.

$\mathrm{O}, \mathrm{C}_{\mathrm{P} 1} ; \bigcirc, \mathrm{C}_{\mathrm{P} 2} ; \triangle, \mathrm{C}_{\mathrm{E} 1} ; \Delta, \mathrm{C}_{\mathrm{E} 2} ; \square, \mathrm{C}_{\mathrm{X} 1} ;$ $\mathrm{C}_{\mathrm{X} 2} ; \diamond, \mathrm{C}_{\mathrm{P} 2}-\mathrm{C}_{\mathrm{P} 2}$.

きる.このために本研究で使用している菌株において

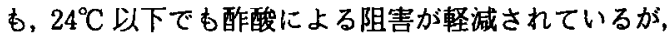
酢酸生産速度が低下したために酢酸濃度が変化しなかっ た可能性がある。

残存エタノールは，酢酸濃度の増加につれて $24^{\circ} \mathrm{C}$ ま では次第に減少し, $24^{\circ} \mathrm{C}$ で 5.1 g-ethanol $/ l(0.64 \%$ (v/ v)）となり，この温度以下ではあまり変化しなかった。 菌体濃度は， $28^{\circ} \mathrm{C}$ に低下させることにより $0.688 \mathrm{~g}-\mathrm{dry}$ cell $/ l$ に増加し，さらに培養温度を低下させるにつれて 漸減したが，平均で $0.624 \mathrm{~g}-\mathrm{dry}$ cell $/ l$ となり第 1 槽に 比較して 5.5 倍高くなった。

（2）酢酸生産速度と酢酸比生産速度

第 1 , 第 2 槽及び 2 つの発酵槽での酶酸生産速度 $\mathrm{r}_{\mathrm{Pl}}$, $\mathrm{r}_{\mathrm{P} 2}$ 及び $\mathrm{r}_{\mathrm{Pt}}$ と第 1 及び第 2 槽での酢酸比生産速度 $\mathrm{Q}_{\mathrm{P} 1}$ 及 び $\mathrm{Q}_{\mathrm{p} 2}$ は，前報と同様に次式で表せる.

$$
\begin{aligned}
& \mathbf{r}_{P 1}=\left(C_{P 1}-C_{P 0}\right) F_{1} / V_{1} \\
& r_{P 2}=\left(C_{P 2}-C_{P 1}\right) F_{2} / V_{2} \\
& r_{P t}=\left(C_{P 2}-C_{P 0}\right) F_{2} /\left(V_{1}+V_{2}\right)
\end{aligned}
$$




$$
\begin{aligned}
& \mathrm{Q}_{\mathrm{P} 1}=\mathrm{r}_{\mathrm{P} 1} / \mathrm{C}_{\mathrm{X} 1} \\
& \mathrm{Q}_{\mathrm{P} 2}=\mathrm{r}_{\mathrm{P} 2} / \mathrm{C}_{\mathrm{X} 2} \\
& \mathrm{C}_{\mathrm{P} 1}{ }^{\prime}=\mathrm{C}_{\mathrm{P} 1} \mathrm{~F}_{1} /\left(\mathrm{F}_{1}+\mathrm{F}_{\mathrm{E}}\right)
\end{aligned}
$$

ここで, $\mathrm{C}_{\mathrm{P} 0}, \mathrm{C}_{\mathrm{P} 1}, \mathrm{C}_{\mathrm{P} 1}{ }^{\prime}$ 及び $\mathrm{C}_{\mathrm{P} 2}$ は供給培地中, 第 1 慒 中，第 2 槽に供給する $\mathrm{F}_{2}$ 中及び第 2 槽中の䣷酸浱度， $\mathrm{F}_{\mathrm{E}}$ は第 2 槽に供給する $99.5 \%(\mathrm{v} / \mathrm{v})$ エタノール夜の供 給速度である。

(1) (6) 式を用いて酢酸生産速度と酢酸比生産速度を 計算し，結果をFig. 2 に示した。

第 1 槽での酢酸生産速度は，温度等の培養条件が一定 であるために $3.8 \mathrm{~g}$-acetic acid/(l $\cdot \mathrm{h})$ の一定值であっ た. 酢酸比生産速度は, $33 \mathrm{~g}$-acetic acid $/(\mathrm{g}$-dry cell $\cdot \mathrm{h})$ という高い値であった，第 2 槽での酢酸生産速度は， $30^{\circ} \mathrm{C}$ では $1.5 \mathrm{~g}$-acetic acid $/(l \cdot \mathrm{h})$ であったが，培養温度 の低下により酢酸濃度が増加したために $24^{\circ} \mathrm{C}$ まで次第 に増加して $2.0 \mathrm{~g}$-acetic acid $/(l \cdot \mathrm{h})$ に増加した。培養温 度をさらに低下させても変化しなかった。

酢酸比生産速度は, 菌体濃度が $28^{\circ} \mathrm{C}$ を頂点に温度の 低下により減少したために，温度の低下により次第に增 加した. $24^{\circ} \mathrm{C}$ での酢酸比生産速度は, $3.0 \mathrm{~g}$-acetic acid/ (g-dry cell · h) ट第 1 槽の值と比較すると $1 / 10$ 以下で あった。これらのこよより，2つの発酵槽での全酢酸生 産速度は, $30^{\circ} \mathrm{C}$ では $2.8 \mathrm{~g}$-acetic acid $/(l \cdot h)$ であった が, $24^{\circ} \mathrm{C}$ まで漸増し, $3.0 \mathrm{~g}$-acetic acid $/(l \cdot h)$ と若干増

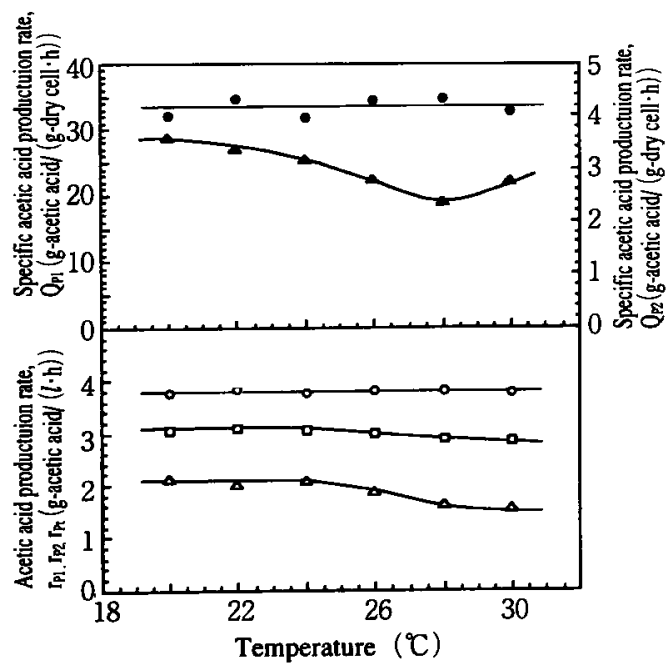

Fig. 2 Effect of cultivation temperature on acetic acid production rate and specific acetic acid production rate

$O, \mathrm{r}_{\mathrm{P} 1} ; \Delta, \mathrm{r}_{\mathrm{P} 2} ; \square, \mathrm{r}_{\mathrm{Pt}} ; \boldsymbol{O}, \mathrm{Q}_{\mathrm{P} 1} ; \Delta, \mathrm{Q}_{\mathrm{P} 2}$.
加した． $24^{\circ} \mathrm{C}$ 以下ではほとんど変化しなかった．また， 全酢酸生産速度に占める $2 つ$ 発酵槽での生産比率は次 式で表せる。

$$
\text { 第 } 1 \text { 槽: }\left(\mathrm{r}_{\mathrm{PI}} \mathrm{V}_{\mathrm{l}}\right) /\left(\mathrm{r}_{\mathrm{Pt}}\left(\mathrm{V}_{1}+\mathrm{V}_{2}\right)\right)
$$

第 2 槽: $\left(r_{\mathrm{P} 2} \mathrm{~V}_{2}\right) /\left(\mathrm{r}_{\mathrm{Pt}}\left(\mathrm{V}_{1}+\mathrm{V}_{2}\right)\right)$

(7) (8) 式を用いて生産比率を計算すると， $24^{\circ} \mathrm{C}$ での第 1 槽と第 2 槽の生産比率は 0.72 と 0.28 となり, 第 1 槽が 2.5 倍程度貢献度が高かった。

(3) 酶酸収率

第 1 槽, 第 2 槽及び 2 つの発酵槽での酢酸収率 $\mathrm{Y}_{\mathrm{P} / \mathrm{S} \text { 1 }}$, $\mathrm{Y}_{\mathrm{P} / \mathrm{S} 2}$ 及び $\mathrm{Y}_{\mathrm{P} / \mathrm{St}}$ は, 前報と同様に次式で表せる.

$$
\begin{aligned}
\mathrm{Y}_{\mathrm{P} / \mathrm{Sl}}= & \left(\mathrm{C}_{\mathrm{P} 1}-\mathrm{C}_{\mathrm{P} 0}\right) / 1.304\left(\mathrm{C}_{\mathrm{E} 0}-\mathrm{C}_{\mathrm{E} 1}\right) \\
\mathrm{Y}_{\mathrm{P} / \mathrm{S} 2}= & \left(\mathrm{C}_{\mathrm{P} 2}-\mathrm{C}_{\mathrm{Pl}}{ }^{\prime}\right) / 1.304\left(\mathrm{C}_{\mathrm{E} 1}{ }^{\prime}-\mathrm{C}_{\mathrm{E} 2}\right) \\
\mathrm{Y}_{\mathrm{P} / \mathrm{St}}= & \left(\mathrm{C}_{\mathrm{P} 2} \mathrm{~F}_{2}-\mathrm{C}_{\mathrm{P} 0} \mathrm{~F}_{1}-\mathrm{C}_{\mathrm{P} 3} \mathrm{~F}_{\mathrm{E}}\right) / \\
& 1.304\left(\mathrm{C}_{\mathrm{E} 0} \mathrm{~F}_{1}+\mathrm{C}_{\mathrm{E} 3} \mathrm{~F}_{\mathrm{E}}-\mathrm{C}_{\mathrm{E} 2} \mathrm{~F}_{2}\right) \\
\mathrm{C}_{\mathrm{E} 1}{ }^{\prime}= & \left(\mathrm{C}_{\mathrm{E} 1} \mathrm{~F}_{1}+\mathrm{C}_{\mathrm{E} 3} \mathrm{~F}_{\mathrm{E}}\right) /\left(\mathrm{F}_{1}+\mathrm{F}_{\mathrm{E}}\right)
\end{aligned}
$$

ここで, $\mathrm{C}_{\mathrm{E} 0}, \mathrm{C}_{\mathrm{E} 1}, \mathrm{C}_{\mathrm{E} 1}{ }^{\prime}, \mathrm{C}_{\mathrm{E} 2}$ 及び $\mathrm{C}_{\mathrm{E} 3}$ は供給培地中, 第 1 槽中, 第 2 槽に供給する $F_{2}$ 中, 第 2 槽中及び $F_{E}$ 中 のエタノール濃度である。

(9)〜(12) 式より収率を計算し, Fig. 3 に示した.

第 1 槽では $0.93 \sim 0.94 \mathrm{~g}$-acetic acid/1.304 g-consumed ethanol の間でほぼ安定していた．第 2 槽では, 若干変動したが培養温度の低下により次第に向上し， $24^{\circ} \mathrm{C}$ では $0.94 \mathrm{~g}$-acetic acid $/ 1.304 \mathrm{~g}$-consumed ethanol であった.このために, 2 つの発酵槽での収率は培養 温度が低いほど収率が向上し， $24^{\circ} \mathrm{C}$ では $0.94 \mathrm{~g}$-acetic acid/1.304 g-consumed ethanolであった.これは，培 養温度の低下により揮発性物質であるエタノールと酢酸 の揮散が抑制されたためと考えられる.

以上のことょり，連続培養においても掊養温度を低下

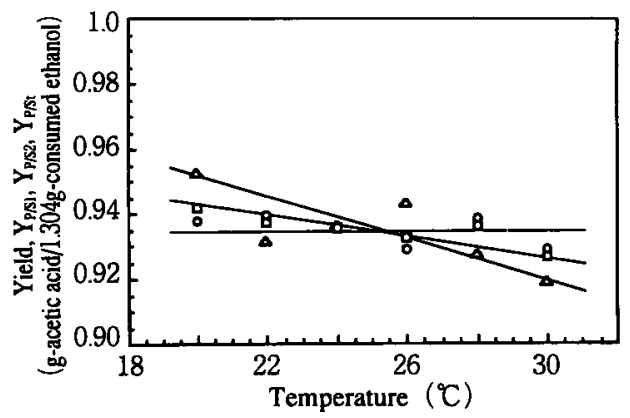

Fig. 3 Effect of cultivation temperature on the yield

$\mathrm{O}, \mathrm{Y}_{\mathrm{P} / \mathrm{S} 1} ; \triangle, \mathrm{Y}_{\mathrm{P} / \mathrm{S} 2} ; \square, \mathrm{Y}_{\mathrm{P} / \mathrm{St} \text {. }}$ 
させることにより回分培養と同様に，酢酸による生産物 阻害を軽減して培養液中の酢酸濃度と酢酸生産速度を向 上でき，目的とする $15 \%(\mathrm{w} / \mathrm{v})$ 以上の酢酸濃度の食酢 を連続的に生産可能であることが認められた。

\section{文献}

1）玉井正弘·丸子 修·門 隆興 : 食科工, 44, 623 (1997).
2）玉井正弘·丸子 修・門 隆興 : 食科工, 44, 119 (1997).

3）玉井正弘 - 丸子 修·門 隆興 : 食科工, 44, 126 (1997)

4）東出敏男 - 奥村 一・川村吉也 - 久松 点 $\cdot$ 山田 哲也：日食工誌，41，913 (1994).

(平成 9 年 1 月 20 日受付，平成 9 年 5 月 22 日受理) 